\title{
Respiratory profile and gill histopathology of Carassius auratus exposed to different salinity concentrations
}

\section{Perfil respiratório e histopatologia das brânquias de Carassius auratus expostas a diferentes concentrações de salinidades}

\begin{abstract}
Weliton Vilhalba da Silva; Henrique Momo Ziemniczak²*; Flávia Barbieri Bacha; Rudã Brandão Santos Fernandes"; Rodrigo Yudi Fujimoto5; Rebeca Maria Sousa6; Klaus Casaro Saturnino7; Claucia Aparecida Honorato ${ }^{8}$
\end{abstract}

\section{Highlights}

Chronic exposure to 5 and $10 \mathrm{~g} \mathrm{~L}^{-1} \mathrm{NaCl}$ altered blood $\mathrm{pH}$ and caused ionic imbalance.

Branchial lesions occurred in fish exposed to acute and chronic salinity.

High salinity had detrimental effects on Carassius auratus survival.

Chronic exposure of Carassius auratus to salinity promoted physiological changes.

\section{Abstract}

The aim of this study was to evaluate the chronic salinity tolerance of Carassius auratus and the effects on blood parameters, gill morphology, and survival. In the first test, nine different concentrations $(0.0,0.5$, 1.0, 2.5, 5.0, 10, 15, 20, and $25 \mathrm{~g} \mathrm{~L}^{-1}$ ) of $\mathrm{NaCl}$ were used with nine repetitions for $96 \mathrm{~h}$. The survival of fish subjected to $15 \mathrm{~g} \mathrm{~L}^{-1} \mathrm{NaCl}$ was $4 \mathrm{~h}$, and $5 \mathrm{~min}$ at a concentration of $25 \mathrm{~g} \mathrm{~L}^{-1}$. The mortality of fish with 15 $\mathrm{g} \mathrm{L}^{-1} \mathrm{NaCl}$ was $100 \%$. Morphological analyses of the gills showed hyperplasia of the coated cells in the interlamellar space and hypersecretion of mucus in fish exposed to $10 \mathrm{~g} \mathrm{~L}^{-1}$ of $\mathrm{NaCl}$. At concentrations of

1 Student of Aquaculture Engenier, Universidade Federal da Grande Dourados, UFGD, Dourados, MS, Brazil. E-mail: weliton_evam@hotmail.com

2 PhD. Student of Animal Science, Universidade Estadual de Londrina, UEL, Londrina, PR, Brazil. E-mail: henrique.momo@hotmail.com

3 PhD. Profa of Centro Universitário da Grande Dourados, UNIGRAN, Dourados, MS, Brazil. E-mail: flaviabacha@ hotmail.com

4 PhD. Yepist Animal Nutrition, YEPIST, Recife, PE, Brazil. E-mail: ruda-fernandes@hotmail.com

5 PhD. Embrapa Tabuleiros Costeiros, Empresa Brasileira de Pesquisa Agropecuária, EMBRAPA CPATC, Aracaju, Sergipe, Brazil. E-mail: ryfujim@hotmail.com

6 PhD. Student of Animal Science, Universidade Federal de Mato Grosso do Sul, UFMS, Campo Grande, MS, Brazil. E-mail: rebe-ca_sousa31@hotmail.com

7 PhD. Prof. of Universidade Federal de Jataí, UFJ, Jataí, GO, Brazil. E-mail: klauscasaro@gmail.com

8 PhD. Profa of Universidade Federal da Grande Dourados, UFGD, Dourados, MS, Brazil. E-mail: clauciahonorato@ ufgd.edu.br

* Author for correspondence

Received: Oct. 21, 2020 - Approved: May 26, 2021 
20 and $25 \mathrm{~g} \mathrm{~L}^{-1}$, necrosis of the support collagen caused the cells to detach from the lamellar structure mucosa. In the chronic test, two concentrations were used, with four replications containing nine fish in each aquarium for a period of 21 days. Blood samples and gills from the fish were collected, and it was observed that the fish showed a decrease in the concentration of bicarbonate $\left(\mathrm{NaHCO}_{3}\right)$ in the blood, indicating hypernatremia. Acute exposure of $\mathrm{C}$. auratus to sodium chloride $(\mathrm{NaCl})$ should be at a maximum of $10 \mathrm{~g} \mathrm{~L}^{-1}$ of $\mathrm{NaCl}$, after which level there would be a loss in animal performance and/or mortality. Chronic exposure to $5 \mathrm{~g} \mathrm{~L}^{-1}$ of $\mathrm{NaCl}$ promotes acidemia, ionic imbalance, and pathological changes in the gills; therefore, it is not recommended.

Key words: Common salt. Concentration. Kinguio. Ornamental fish. Osmoregulation.

\section{Resumo}

O objetivo deste estudo foi avaliar a tolerância crônica de Carassius auratus à salinidade e os efeitos sobre os parâmetros sanguíneos, morfologia branquial e sobrevivência. No primeiro teste, foram utilizadas nove concentrações de $\mathrm{NaCl}\left(0.0,0.5,1.0,2.5,5.0,10,15,20\right.$, e $\left.25 \mathrm{~g} \mathrm{~L}^{-1}\right)$ e nove repetições por $96 \mathrm{~h}$. A sobrevivência dos peixes submetidos a até $15 \mathrm{~g} \mathrm{~L}^{-1} \mathrm{de} \mathrm{NaCl}$ foi de $04 \mathrm{~h} 00$, sendo $00 \mathrm{~h} 05$ na concentração de $25 \mathrm{~g} \mathrm{~L}^{-1}$ de NaCl. A mortalidade dos peixes com $15 \mathrm{~g}$ foi de 100\%. As análises morfológicas das brânquias mostraram hiperplasia das células revestidas no espaço interlamelar e hipersecreção de muco em peixes expostos a uma concentração de $10 \mathrm{~g} \mathrm{~L}^{-1}$ de NaCl. Nas concentrações de 20 e $25 \mathrm{~g} \mathrm{~L}^{-1}$, observou-se que a colágeno de suporte perdeu a estrutura das células da mucosa, alterando as lamelas secundárias. Em um segundo experimento, um delineamento inteiramente casualizado foi utilizado com dois tratamentos ( 0 e 5 $\mathrm{g} \mathrm{L}^{-1}$ de $\mathrm{NaCl}$ ) e quatro repetições com nove peixes por $30 \mathrm{~L} \mathrm{em} 21$ dias. Amostras de sangue e brânquias dos peixes foram coletadas e observou-se que os peixes apresentaram diminuição nas concentrações de bicarbonato $\left(\mathrm{NaHCO}_{3}\right.$ ) no sangue, indicando hipernatremia. Conclui-se que a exposição aguda de $\mathrm{C}$. auratus ao cloreto de sódio $(\mathrm{NaCl})$ deve ser de no máximo $10 \mathrm{~g} \mathrm{~L}^{-1}$, levando à perda de desempenho e/ou mortalidade dos animais. A exposição crônica a $5 \mathrm{~g} \mathrm{~L}^{-1}$ de $\mathrm{NaCl}$ promove acidemia, desequilíbrio iônico e alterações patológicas nas brânquias, por isso não é recomendado.

Palavras-chave: Sal comum. Concentração. Kinguio. Osmorregulação. Peixes ornamentais.

\section{Introduction}

The ornamental fish market has a value of approximately US $\$ 15$ billion, mainly from the commercialization of captive-bred specimens (Food and Agriculture Organization of the United Nations [FAO], 2010). It contributes to rural progress in many developing countries and positively impacts expanding economies (Ashley, 2007). The growing interest in aquarium fish has resulted in a steady increase in the global industry, with a turnover of US\$
372 billion (FAO, 2017). Among the ornamental species of commercial interest, Carassius auratus is predominant because of its docility, robustness, and pleasing appearance in the aquarium environment (Bandyopadhyay, Swain, \& Mishra, 2005).

Although ornamental aquaculture is common in Brazil, fish production is conducted by intensive farming with rudimentary handling (Moyses, Spadacci-Morena, Xavier, Antonucci, \& Lallo 2015). Fish in aquaculture farms are 
often subjected to acute or chronic stressors such as handling, transportation, sorting, temperature change, high rearing density, and poor water quality. These factors affect fish physiology and their growth, behavior, and welfare (Ullah, Li, Hasan, Khan, \& Fahad, 2018). In husbandry practices, saline water is commonly used to reduce handling and transportation stress in freshwater species (Mirghaed \& Ghelichpour, 2019) and for treatment of certain diseases (Smith, Kane, \& Popper, 2003; Moyses et al., 2015).

Changes in environmental $\mathrm{NaCl}$ content challenge the physiological homeostasis and biological processes of an organism (Kültz, 2015) and can cause death (Urbina \& Glover, 2015) or affect growth performance (Rahmah, Liew, Napi, \& Rahmat, 2020), blood parameters (Ullah et al., 2018), plasma osmolality, respirometry responses (Nordlie, 2009), histopathology, or behavior (Abe, Dias, Cordeiro, Ramos, \& Fujimoto, 2015; Honorato \& Nascimento, 2016). Unsuitable $\mathrm{NaCl}$ dosage can lead to dehydration and hypernatremia, causing homeostasis disturbances (Mattioli et al., 2017) and susceptibility to infectious diseases (Choi, Cope, Harms, \& Law, 2013). Despite the negative effects of salinity, some reports have shown growth improvement in seawater-reared freshwater fish under suitable salinity ranges (Sparks et al., 2003).

Adapting to salinity changes requires extra energy to maintain iono-osmotic balance, influencing fish metabolic needs and promoting changes in respiratory responses (Honorato, Dambros, Marcondes, \& Nascimento, 2014). Most studies on the metabolic responses of fish to the use of $\mathrm{NaCl}$ do not focus on the respiratory and histological responses of gills.

In the captive breeding of goldfish, the recommended concentration of $\mathrm{NaCl}$ is $6 \mathrm{~g} \mathrm{~L}^{-1}$, which has been used in the longterm without causing stress and loss in zootechnical performance (Luz \& Santos, 2008). However, the electrolytic adaptations and conformations of the gills have not been described. Exposure of freshwater fish to salinity may affect the morphological characteristics (Lisboa, Barcarolli, Sampaio, \& Bianchini, 2015) of various tissues. Salinity is a major environmental factor that affects the physiology of aquatic organisms, as changes in ambient salinity can directly influence fish metabolism (Boeuf \& Payan, 2001; Nordlie, 2009; Anni et al., 2016). Therefore, several studies have been conducted regarding the influence of salinity on the growth of fish, including with C. auratus (Luz \& Santos, 2008). Regulation is achieved through a range of ionic and osmoregulatory processes that demand energy (Nordlie, 2009; Lisboa et al., 2015). In this context, alterations in hematocrit values usually reflect changes in blood water content and/or metabolic rate (Iwama, McGeer, \& Pawluk, 1989; Prodocimo, Souza, Pessini, Fernandes, \& Freire, 2008).

The objectives of this study were to evaluate the sub-chronic sensitivity of Carassius auratus to different concentrations of $\mathrm{NaCl}$ and to assess the possible changes in the gills, ionic regulation, and respiratory metabolism after chronic exposure. 


\section{Material and Methods}

\section{Location and animals}

Two experimental tests were conducted: one for acute tolerance (Experiment I) and the other for chronic tolerance (Experiment II). Specimens of the ornamental fish Carassius auratus were used with mean weight of 5.53 $\pm 1.04 \mathrm{~g}$ and mean length of $5.53 \pm 0.38 \mathrm{~cm}$. The water quality was documented. The tests were conducted in the Animal Production Laboratory at the University Center of Grand Dourados - UNIGRAN, Dourados-MS, Brazil.

The procedures performed on experimental fish were in accordance with institutional ethics and approved by the Animal Experimentation Ethics Committee AEEC 004/14.

\section{Acute tolerance}

A completely randomized design was carried out with nine differences salinities of (Zuanon, Salaro, Veras, Tavares, \& Chaves, $2009) \mathrm{NaCl}$ in water $(0,0.5,1.0,2.5,5.0,10,15$, 20 , and $\left.25 \mathrm{~g} \mathrm{~L}^{-1}\right)$. The concentrations used were based on Luz and Santo (2008) on tolerance of Carassius auratus and on Zuanon et al. (2009) on table salt.

For this test, three repetitions were used, containing three fish per experimental unit, for $96 \mathrm{~h}$ to measure the LD50. LD50 was expressed as the concentration of $\mathrm{NaCl}$ resulting in the death of $50 \%$ of the fish.

The fish were kept in a $1 \mathrm{~L}$ aquarium, maintained at a temperature of $27{ }^{\circ} \mathrm{C}$ and photoperiod of $12 \mathrm{~h}$ of light, with constant aeration. The waste from the tank was siphoned, and water was replaced with the same salinity for each treatment. The temperature, dissolved oxygen, and $\mathrm{pH}$ were measured daily. Every hour during the first six hours, and subsequently at six-hour intervals, fish mortality (determined as fish having no reaction to external changes, and no opercular movement) was verified over the $96 \mathrm{~h}$ of exposure.

After saline exposure and death verification, nine fish from each $\mathrm{NaCl}$ concentration were removed, and the gills of these animals were extracted for histological analysis. Fragments of the gills were soaked in a formalin (0.1 M; pH 7.3) buffered solution for $24 \mathrm{~h}$ and subsequently stored in $70 \%$ alcohol until processed. After fixation, they were dehydrated, diaphanized, and placed in plastic polymer (Histosec, Merck ${ }^{\circledR}$ ). A microtomy was then performed to obtain $5 \mu \mathrm{m}$ histological slides, which were stained with hematoxylineosin.

\section{Chronic tolerance}

Chronic tolerance was assessed using the results of the acute test. Seventy-two specimens of Carassius auratus were exposed to $5 \mathrm{~g} \mathrm{~L}^{-1}$ of $\mathrm{NaCl}$ for 21 days. The waste was removed and water was added with the same salinity each day. The experimental design was completely randomized with two treatments and four replicates (nine fish per aquarium).

The fish were distributed into eight aquariums (30 L) with constant aeration. Feeding was administered twice a day to apparent satiety with extruded commercial feed $(32 \% \mathrm{CP})$.

After 21 days of exposure to $\mathrm{NaCl}$, the fish from all aquaria were counted and captured for blood collection, which was 
performed by puncturing the caudal vein using a $3 \mathrm{~mL}$ heparinized syringe. After blood collection, the fish were euthanized by a medullary section and the gills were removed. Blood was analyzed using a respirometry response apparatus (Cobas HB121; Roche Diagnostic Brazil, São Paulo, SP, Brazil). The sodium $(\mathrm{Na}+)$, potassium $\left(\mathrm{K}^{+}\right)$and chloride $\left(\mathrm{Cl}^{-}\right.$ ) levels were measured, along with respiratory parameters in the blood such as $\mathrm{pH}_{1} \mathrm{H}^{+}$, bicarbonate concentration $\left(\mathrm{HCO}_{3}^{-}\right)$, partial oxygen pressure $\left(\mathrm{PO}_{2}\right)$, and partial carbon dioxide pressure $\left(\mathrm{PCO}_{2}\right)$ (Cobas $\mathrm{HB121}$; Roche Diagnostic Brazil, São Paulo, SP, Brazil).

For histological analyses, gill fragments were soaked in buffered formalin solution (0.1 $\mathrm{M} ; \mathrm{pH}$ 7.3) for $24 \mathrm{~h}$ and stored in $70 \%$ alcohol until processed. After fixation, they were dehydrated, diaphanized in xylol, embedded, and included in plastic polymer (Histosec, Merck $\left.^{\circledR}\right)$. A microtomy was then performed to obtain 2-5 $\mu \mathrm{m}$ histological slides, which were stained with hematoxylin-eosin, and analyzed for changes.

\section{Results and Discussion}

\section{Experiment I - Acute tolerance}

Fish subjected to concentrations of $0,0.5,1.0,2.5,5.0$, and $10 \mathrm{~g} \mathrm{~L}^{-1}$ of $\mathrm{NaCl}$ showed $100 \%$ survival, whereas $0 \%$ survival occurred with exposure to $15 \mathrm{~g} \mathrm{~L}^{-1} \mathrm{NaCl}$. The survival time in $15 \mathrm{~g} \mathrm{~L}^{-1}$ of $\mathrm{NaCl}$ was four $\mathrm{h}$, and approximately five min in concentrations of 20 and $25 \mathrm{~g} \mathrm{~L}^{-1}$. The LD50 occurred at $11.52 \mathrm{~g} \mathrm{~L}^{-1}$ of $\mathrm{NaCl}\left(\mathrm{R}^{2}=0.802\right)$

The average index for dissolved oxygen was $5.70 \pm 0.2 \mathrm{mg} \mathrm{L}^{-1}$, average temperature was $26.27 \pm 1.20$, with a $\mathrm{pH}$ of $7.95 \pm 0.03$. Fish subjected to 15,20 , and $25 \mathrm{~g} \mathrm{~L}^{-1} \mathrm{NaCl}$ showed changes in behavior characterized by agitation and erratic swimming.

Fish subjected to water salinity up to $15 \mathrm{~g} \mathrm{~L}^{-1}$ exhibited diffuse detachment of the brachial epithelium, associated with mild cellular hyperplasia in the interlamellar space (Figure 1A). At concentrations of 20 and $25 \mathrm{~g} \mathrm{~L}^{-1}$, slight morphological changes were observed, such as moderate vascular congestion of the secondary lamellae (Figure $1 \mathrm{~B}$ ).
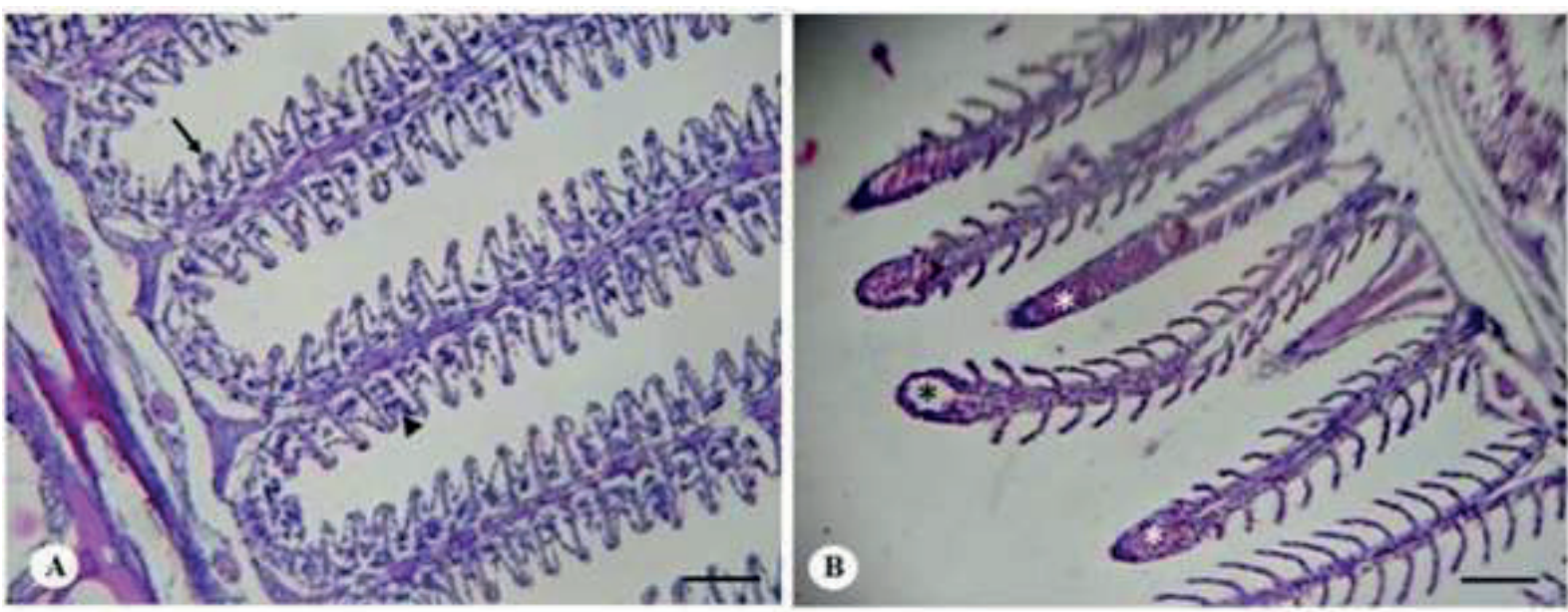

Figure 1. Branchial lamellae. (A) Treatment with $15 \mathrm{~g} \mathrm{~L}^{-1}$ of $\mathrm{NaCl}$. Diffuse detachment of the branchial epi-thelium (arrow) and discrete fusion (arrowhead) of secondary lamella. (B) Treatment with $20 \mathrm{~g}$ $\mathrm{L}^{-1}$ of $\mathrm{NaCl}$. Note moderate venous congestion (asterisks). 200x, HE. Bar $=50 \mu \mathrm{m}$. 


\section{Experiment II - Chronic tolerance}

The water quality remained constant (dissolved oxygen $5.70 \pm 0.2 \mathrm{mg} \mathrm{L}^{-1}$, temperature $26.27 \pm 1.20{ }^{\circ} \mathrm{C}, \mathrm{pH} 7.95 \pm 0.03$ ) in all aquaria except for electrical conductivity (the control showed $0.48 \mathrm{mS} \mathrm{cm}^{-1}$, while the $5 \mathrm{~g}$ $\mathrm{L}^{-1} \mathrm{NaCl}$ returned $0.93 \mathrm{mS} \mathrm{cm}^{-1}$ ) that was higher in the aquaria exposed to $\mathrm{NaCl}$, represented by an increase of $94.84 \%$.

Fish exposed to $\mathrm{NaCl}$ became lethargic, with increased mucus production and altered opercular beats. In addition, a reduction in food consumption was observed in fish subjected to $5 \mathrm{~g} \mathrm{~L}^{-1} \mathrm{NaCl}$. The survival rate was $100 \%$ for the control group and $75 \%$ for the group exposed to $5 \mathrm{~g} \mathrm{~L}^{-1} \mathrm{NaCl}$.

The chronic tolerance of $C$. auratus promoted metabolic acidosis, as evidenced by the decrease in blood bicarbonate concentrations. With respect to the respiratory parameters, there was an increase in oxygen pressure, and consequently, in the saturation of $\mathrm{O}_{2}$ (Table 1).
Blood electrolytes revealed changes. Blood sodium and chloride concentrations increased by $5 \%$ and $25 \%$, respectively, showing hypernatremia and hyperchloremia (Table 1). The blood potassium concentration decreased by $66 \%$ in comparison to the control group, which is typical of hypotassemia.

The gills of the fish kept in fresh water (control) exhibited a normal histoarchitecture consisting of primary lamellae that formed secondary lamellae at regular intervals, composed of two layers of pavement epithelial cells, pillar cells, chloride cells, and mucosal cells.

Chronic tolerance to $5 \mathrm{~g} \mathrm{~L}^{-1}$ of $\mathrm{NaCl}$ in $\mathrm{C}$. auratus promoted alterations in the structure of the gills with hypersecretion of mucus and displacement of the epithelium proliferation of chloride cells, edema, telangiectasia (Figure $2 \mathrm{~A})$, and the proliferation of mucosal cells (Figure 2B).

\section{Table 1}

Blood parameters of Carassius auratus after 21 days of storage in water salinity

\begin{tabular}{|c|c|c|}
\hline Variation & Control & $5 \mathrm{~g} \mathrm{~L}^{-1} \mathrm{de} \mathrm{NaCl}$ \\
\hline $\mathrm{pH}$ & $7.02 \pm 0.04^{a}$ & $6.98 \pm 0.02^{b}$ \\
\hline $\mathrm{H}_{2} \mathrm{CO}_{3}\left(\mathrm{mmol} . \mathrm{L}^{-1}\right)$ & $4.4 \pm 0.50^{\mathrm{a}}$ & $1.77 \pm 0.09^{b}$ \\
\hline $\mathrm{H}+\left(\mathrm{mmol} . \mathrm{L}^{-1}\right)$ & $62.2 \pm 3.18^{a}$ & $105.0 \pm 3.30^{b}$ \\
\hline \multicolumn{3}{|l|}{ Breathing variation } \\
\hline $\mathrm{PCO}_{2}(\mathrm{mmHg})$ & $11.40 \pm 1.40^{\mathrm{a}}$ & $7.10 \pm 0.60^{b}$ \\
\hline $\mathrm{PO}_{2}(\mathrm{mmHg})$ & $60.50 \pm 8.25^{\mathrm{a}}$ & $114.85 \pm 6.55^{b}$ \\
\hline Saturation of $\mathrm{O}_{2}(\%)$ & $80.57 \pm 5.48^{a}$ & $93.25 \pm 0.25^{b}$ \\
\hline \multicolumn{3}{|c|}{ Electrolytes $\left(\mathrm{mmol} \mathrm{L}^{-1}\right)$} \\
\hline Sodium $\left(\mathrm{Na}^{+}\right)$ & $161.4 \pm 1.13^{a}$ & $170.7 \pm 0.35^{b}$ \\
\hline Potassium $\left(\mathrm{K}^{+}\right)$ & $6.33 \pm 0.44^{a}$ & $4.2 \pm 0.06^{b}$ \\
\hline Chloride $\left(\mathrm{Cl}^{-}\right)$ & $163.0 \pm 0.48^{\mathrm{a}}$ & $204.2 \pm 1.81^{b}$ \\
\hline
\end{tabular}


The lethal nature of $\mathrm{NaCl}$ to freshwater fish is an expected effect due to the loss of water to the environment that is characteristic of stenohaline fishes (Fashina-Bombata \& Busari, 2003). The tolerance range of fish to saline water depends on characteristics such as fish species, age, and size (Luz \& Santos, 2008), as well as the osmoregulatory characteristics of each species (Rahmah et al., 2020).
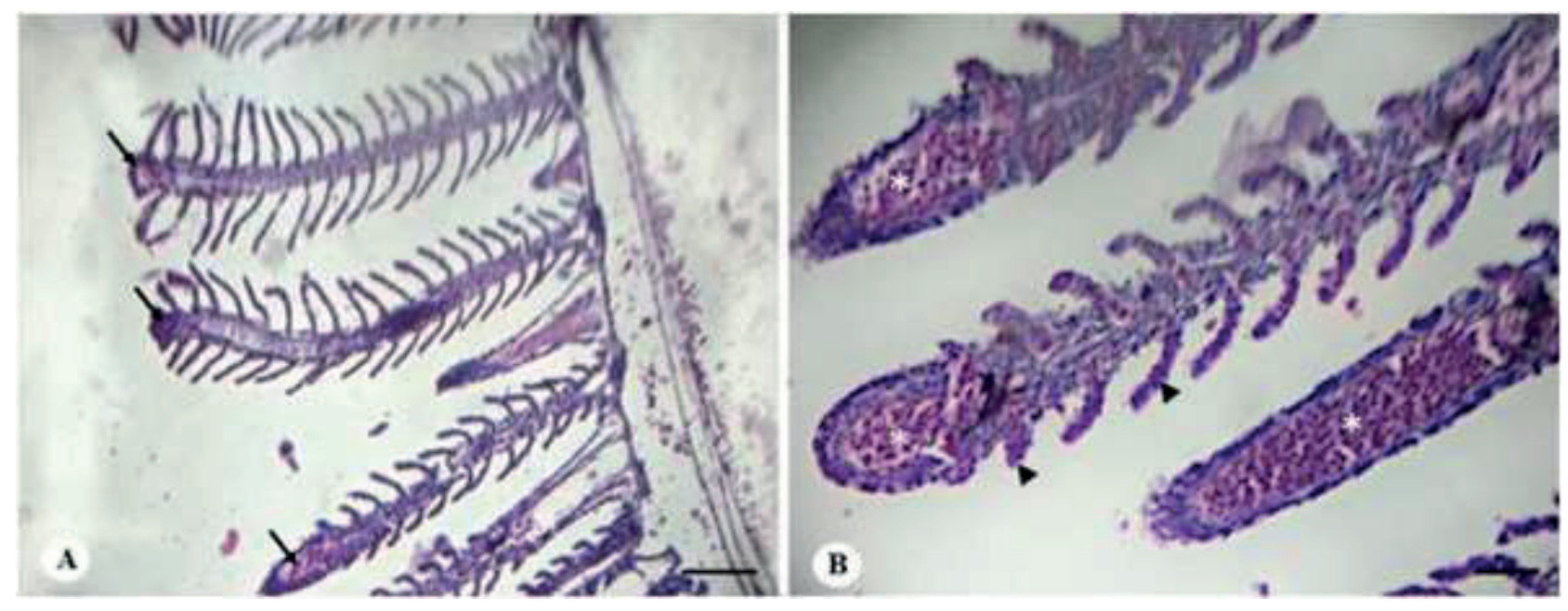

Figure 2. Branchial lamellae. Treatment with $5 \mathrm{~g} \mathrm{~L}^{-1}$ of $\mathrm{NaCl}$ for 21 days. (A) Presence of lamella venous congestion (arrow). HE, 200x. Bar $=50 \mu \mathrm{m}$. (B) Presence of moderate venous congestion in primary lamella (asterisks) including secondary lamellae (arrowhead). 400x, HE. Bar $=20 \mu \mathrm{m}$.

Qualitative analysis revealed that the aquatic environment influenced the tissue morphology of the gills. Similar observations were made when fish were subjected to stress, such as hyperplasia at the tip of the filaments and in the tilapia lamellae in fish confined to a reduced space (Reis, Sant'Ana, Azevedo, Merlini, \& Araújo, 2009); proliferation of epithelial cells in the gill filaments and lamellae, lamellar fusion, and mucosal cell hyperplasia in juvenile brown trout exposed to heavy metals and pesticides (Schwaiger et al., 1997); and urban pollution in Danio rerio from contaminated rivers (Fracácio et al., 2003). Exposure of the fish to different salinity levels is often reflected by morphological alterations
(Okamoto et al., 2009) and cell structure modifications (Carmona, García-Gallego, Sanz, Domezaín, \& Ostos-Garrido, 2004). Lin, Huang, Yang, Lee and Hwang (2004) observed an increase in the number of chloride cells in the gill epithelium of tilapias (Oreochromis mossambicus) associated with exposure to salinity. Thus, the present study corroborates the literature, which describes the appearance of these morphological changes when fish are exposed to stress. In addition, the absence of lesions in animals exposed to concentrations up to $15 \mathrm{~g} \mathrm{~L}^{-1}$ is justified by the rapid evolution of the process, without the development of structural changes visible under microscopy. 
These histopathological injuries damage the morphological-functional integrity of the gill, reducing its efficiency in performing physiological functions (Henares, Cruz, Gomes, Pitelli, \& Machado, 2008). The alterations observed in the gills of fish exposed to salinity resulted in changes to the gas exchange process. The increase in mucous cells causes hypersecretion of mucus, which can lead to protection of the tissue structure in adverse environmental situations and exposure to possible toxicants (Mazon, Cerqueira, \& Fernandes, 2002; Henares et al., 2008).

Exposure of fish to chronic salinity tolerance revealed lethargy with increased mucous production and changes in opercular beats, as well as a decreased food consumption. The low feed intake of the fish exposed to salinity can be attributed to manifestations such as irritation, agitation, and lethargy (Farshadian, Salati, Keyvanshokooh, \& Pasha-Zanoosi, 2018).

Survival reflected the level of dehydration of freshwater fish when exposed to saline water (Fashina-Bombata \& Busari, 2003). These cumulative changes are the morphophysiological adaptations of $C$. auratus exposed to $\mathrm{NaCl}$. The prolonged exposure of the fish to $\mathrm{NaCl}$ caused alterations to the gaseous exchanges, which promoted an increase in the concentration of $\mathrm{H}^{+}$. When the concentration of $\mathrm{H}^{+}$in the blood increases $(\mathrm{pH}<7.40)$, acidemia occurs, which may be secondary to metabolic or respiratory acidosis. Metabolic acidosis is the result of a process that increases the concentration of $\mathrm{H}^{+}$and decreases the concentration of $\mathrm{HCO}_{3}{ }^{-}$ in the blood (Carlotti, 2012) and insufficient $\mathrm{HCO}_{3}{ }^{-}$inhibits the blood $\mathrm{pH}$-lowering buffer effect due to changes in the gaseous exchange processes in the gills, which could be fatal.

The chronic tolerance of $C$. auratus promotes metabolic acidosis, as evidenced by the decrease in blood bicarbonate concentrations. In fish, specialized tissues and organs, such as the gills and intestines are responsible for maintaining the hydromineral balance (Varsamos, Nebel, \& Charmantier, 2005). Fish can maintain the internal osmotic concentration and ionic homeostasis at different salinity gradients, which allows the normal functioning of the cells and physiological systems for the survival of the species (Hwang \& Lee, 2007). Freshwater species may increase tolerance to different salinity gradients during ontogenetic development (Luz \& Santos, 2008). However, there is a limit to ensure that the effectiveness of this osmoregulation mechanism is not compromised in fish (Jomori, Luz, Takata, Fabregat, \& Portella, 2013).

Freshwater fish eliminate excess water via osmosis. This is accomplished by producing a relatively high volume of diluted urine (Evans, Piermarini, \& Choe, 2005). Since $\mathrm{NaCl}$ is lost by diffusion through the gills and integument and there is a small ionic loss via urine, these fish use chloride cells, and possibly other cells of the gill epithelium, to transport sodium and chloride from the water to the blood using ATP and the enzyme $\mathrm{Na}^{+}$I $\mathrm{K}^{+}$- ATPase (Moraes, Avilez, Altran, \& Barbosa, 2002).

The regulation promoted by chloride cells and $\mathrm{Na}^{+} / \mathrm{K}^{+}$ATPase is critical during the movement of fish in brackish water. $\mathrm{Na}^{+} / \mathrm{K}^{+}$ ATPase generates a low concentration of intracellular sodium and a high concentration of negative charges within the cell. The $\mathrm{Na}$ 
gradient is then used to transport chloride from the interior of the cell through $\mathrm{Na}^{+} / \mathrm{K}^{+}$ATPase co-transport. Thus, $\mathrm{Cl}^{-}$leaves the cell under an electrical gradient through $\mathrm{Cl}^{-}$apical channels (Varsamos et al., 2005).

The main component of ionic imbalance is the increase in membrane permeability, which favors the loss of $\mathrm{NaCl}$ to the external and less concentrated environment by the concentration gradient (Diniz \& Honorato, 2012).

The fish in this study that were exposed to chronic salinity exhibited hypernatremia, which may be related to the decrease in membrane permeability, altering the ionic exchange. However, this is an indication that the fish are hyperventilating to eliminate sodium through the gills. With high salinity, the number of chloride cells, and the activity of $\mathrm{Na}^{+} / \mathrm{K}^{+}$-ATPase and carbonic anhydrase increases (Evans et al., 2005). Hypernatremia evolves with hyperosmolality and causes cell dehydration, which can lead to changes in the central nervous system.

\section{Conclusion}

Carassius auratus tolerated acute salinity transfer between 0 and $10 \mathrm{~g} \mathrm{~L}^{-1}$ without gill lesions. Chronic tolerance to $5 \mathrm{~g}$ $\mathrm{L}^{-1}$ promotes acid base imbalance and ionic imbalance (increase in $\mathrm{NaCl}$ and a decrease in blood $\mathrm{K}^{+}$).

\section{References}

Abe, H. A., Dias, J. A. R., Cordeiro, C. A. M., Ramos, F. M., \& Fujimoto, R. Y. (2015). Pyrrhulina brevis (Steindachner, 1876) as a new option for national ornamental fish farming: larviculture. Boletim do Instituto de Pesca, 41(1), 113-122. Retrieved from https://www.pesca.sp.gov.br/boletim/ index.php/bip/article/view/41_1_113-122

Anni, I. S. A., Bianchini, A., Barcarolli, I. F., Varela, A. S., Jr., Robaldo, R. B., Tesser, M. B., \& Sampaio, L. A. (2016). Salinity influence on growth, osmoregulation and energy turnover in juvenile pompano Trachinotus marginatus Cuvier 1832. Aquaculture, 455, 63-72. doi: 10.1016/j. aquaculture.2016.01.010

Ashley, P. J. (2007). Fish welfare: current issues in aquaculture. Applied Animal Behaviour Science, 104(3-4), 199-235. doi: 10.1016/j.applanim.2006.09.001

Bandyopadhyay, P., Swain, S. K., \& Mishra, S. (2005). Growth and dietary utilization in goldfish (Carassius auratus Linn.) fed diets formulated with various local agroproduces. Bioresource Technology, 96(6), 731-40. doi: 10.1016/j.biortech.2004.06. 018

Boeuf, G., \& Payan, P. (2001). How should salinity influence fish growth? Comparative Biochemistry and Physiology Part C: Toxicology \& Pharmacology, 130(4), 411-423. doi: 10.1016/S1532-0456(01) 00268-X

Carlotti, A. P. C. P. (2012). Abordagem clínica dos distúrbios do equilíbrio ácido-base. Medicina (Ribeirão Preto Online), 45(2), 244-262. doi: 10.11606/issn.2176-7262. v45i2p244-262

Carmona, R., García Gallego, M., Sanz, A., Domezaín, A., \& Ostos Garrido, M. V. (2004). Chloride cells and pavement cells in gill epithelia of Acipenser naccarii: 
ultrastructural modifications in seawater acclimated specimens. Journal of Fish Biology, 64(2), 553-566. doi: 10.1111/j.00 22-1112.2004.00321.x

Choi, K., Cope, W. G., Harms, C. A., \& Law, J. M (2013). Rapid decrease in salinity, but not increases, lead to immune dysregulation in Nile tilapia, Oreochromis niloticus (L.). Journal of Fish Diseases, 36(4), 389-399. doi: 10.1111/j.1365-2761.2012.01417.x

Diniz, N. M., \& Honorato, C. A. (2012). Algumas alternativas para diminuir os efeitos do estresse em peixes de cultivo-revisão. Arquivos de Ciências Veterinárias e Zoologia da UNIPAR, 15(2), 149-154. Recuperado de https://www.revistas. unipar.br/index.php/veterinaria/article/ view/4219

Evans, D. H., Piermarini, P. M., \& Choe, K. P. (2005). The multifunctional fish gill: dominant site of gas exchange, osmoregulation, acid-base regulation, and excretion of nitrogenous waste. Physiological Reviews, 85(1), 97-177. doi: 10.1152/physrev.00050.2003

Farshadian, R., Salati, A. P., Keyvanshokooh, S., \& Pasha-Zanoosi, H. (2018). Physiological responses of Yellowfin seabream (Acanthopagrus latus) to acute salinity challenge. Marine and Freshwater Behaviour and Physiology, 51(5), 313-325. doi: 10.1080/10236244.2019.1573638

Fashina-Bombata, H. A., \& Busari, A. N. (2003). Influence of salinity on the developmental stages of African catfish Heterobranchus longifilis (Valenciennes, 1840). Aquaculture, 224(1-4), 213-222. doi: 10.1016/S0044-8486(03)00273-4
Food and Agriculture Organization of the United Nations (2010). The State of world fisheries and aquaculture. Rome, Italy: FAO. Retrieved from http://www.fao.org/3/ i1820e/i1820e.pdf

Food and Agriculture Organization of the United Nations (2017). Fish industry recognizing ornamental fish trade at the 2nd International. Ornamental Fish Trade and Technical Conference. Retrieved from http://www.fao.org/in-action/globefish/ news-events/details-news/en/c/469648/

Fracácio, R., Verani, N. F., Espíndola, E. L. G., Rocha, O., Rigolin-Sá, O., \& Andrade, C. A. (2003). Alterations on growth and gill morphology of Danio rerio (Pisces, Ciprinidae) exposed to the toxic sediments. Brazilian archives of Biology and Technology, 46(4), 685-695. doi: 10.1590/S1516-89132003000400023

Henares, M. N. P., Cruz, C., Gomes, G. R., Pitelli, R. A., \& Machado, M. R. F. (2008). Toxicidade aguda e efeitos histopatológicos do herbicida diquat na brânquia e no fígado da tilápia nilótica (Oreochromis niloticus). Acta Scientiarum. Biological Sciences, 30(1), 77-82. doi: 10.4025/actascibiolsci. v30i1.1462

Honorato, C. A., Dambros, A., Marcondes, V. M., \& Nascimento, C. A. (2014). Utilização do eugenol em jundiá da Amazônia (Leiarius marmoratus): implicações na sedação e avaliação hemogasométrica. Semina: Ciências Agrárias, 35(5), 2759-2767. doi: 10.5433/1679-0359.2014v35n5p2759

Honorato, C. A., \& Nascimento, C. A. (2016). Metabolismo respiratório e da glicose de Carassius auratus submetidos a 
concentrações de eugenol. Revista Brasileira de Saúde e Produção Animal, 17(3), 545-552. doi: 10.1590/S1519-9940 2016000300019

Hwang, P. P., \& Lee, T. H. (2007). New insights into fish ion regulation and mitochondrionrich cells. Comparative Biochemistry and Physiology Part A: Molecular \& Integrative Physiology, 148(3), 479-497. doi: 10.1016/j.cbpa.2007.06.416

Iwama, G. K., McGeer, J. C., \& Pawluk, M. P. (1989). The effects of five fishanaesthetics on acid-base balance, hematocrit, blood gases, cortisol, and adrenaline in rainbow trout. Canadian Journal of Zoology, 67(8), 2065-2073. doi: 10.1139/z89-294

Jomori, R. K., Luz, R. K., Takata, R., Fabregat, T. E. H. P., \& Portella, M. C. (2013). Água levemente salinizada aumenta a eficiência da larvicultura de peixes neotropicais. Pesquisa Agropecuária Brasileira, 48(8), 809-815. doi: 10.1590/S0100-204X2013 000800001

Kültz, D. (2015). Physiological mechanisms used by fish to cope with salinity stress. Journal of Experimental Biology, 218(12), 1907-1914. doi: 10.1242/jeb.118695

Lin, C. H., Huang, C. L., Yang, C. H., Lee, T. H., \& Hwang, P. P. (2004). Time course changes in the expression of $\mathrm{Na}$, KATPase and the morphometry of mitochondrion rich cells in gills of euryhaline tilapia (Oreochromis mossambicus) during freshwater acclimation. Journal of Experimental Zoology Part A: Comparative Experimental Biology, 301(1), 85-96. doi: 10.1002/jez.a. 20007
Lisboa, V., Barcarolli, I. F., Sampaio, L. A., \& Bianchini, A. (2015). Effect of salinity on survival, growth and biochemical parameters in juvenile Lebranche mullet Mugil liza (Perciformes: Mugilidae). Neotropical Ichthyology, 13(2), 447-452. doi: 10.1590/1982-0224-20140122

Luz, R. K., \&Santos, J. C. E. dos. (2008). Avaliação da tolerância de larvas do pacamã Lophiosilurus alexandri Steindachner, 1877 (Pisces: Siluriformes) a diferentes salinidades. Acta Scientiarum. Biological Sciences, 30(4), 345-350. doi: 10.4025/ actascibiolsci.v30i4.791

Mattioli, C. C., Takata, R., Leme, F. D. O. P., Costa, D. C., Melillo, R., Fo., Silva, W. D. S. e, \& Luz, R. K. (2017). The effects of acute and chronic exposure to water salinity on juveniles of the carnivorous freshwater catfish Lophiosilurus alexandri. Aquaculture, 481, 255-266. doi: 10.1016/j.aquaculture. 2017.08.016

Mazon, A. F., Cerqueira, C. C. C., \& Fernandes, M. N. (2002). Gill cellular changes induced by copper exposure in the South American tropical freshwater fish Prochilodus scrofa. Environmental Research, 88(1), 52-63. doi: 10.1006/enrs.2001.4315

Mirghaed, A. T., \& Ghelichpour, M. (2019). Effects of anesthesia and salt treatment on stress responses, and immunological and hydromineral characteristics of common carp (Cyprinus carpio, Linnaeus, 1758) subjected to transportation. Aquaculture, 501, 1-6. doi: 10.1016/j. aquaculture.2018.11.008 
Moraes, G., Avilez, I. M., Altran, A. E., \& Barbosa, C. C. (2002). Biochemical and hematological responses of the banded knife fish Gymnotus carapo (Linnaeus, 1758) exposed to environmental hypoxia. Brazilian Journal of Biology, 62(4A), 633-640. doi: 10.1590/S1519-6984200 2000400011

Moyses, C.R. S., Spadacci-Morena, D. D., Xavier, J. G., Antonucci, A. M., \& Lallo, M. A. (2015). Ectocommensal and ectoparasites in goldfish Carassius auratus (Linnaeus, 1758) in farmed in the State of São Paulo. Revista Brasileira de Parasitologia Veterinária, 24(3), 283-289. doi: 10.1590/ S1984-296 12015054

Nordlie, F. G. (2009). Environmental influences on regulation of blood plasma/serum components in teleost fishes: a review. Reviews in Fish Biology and Fisheries, 19(4), 481-564. doi: 10.1007/s11160009-9131-4

Okamoto, T., Kurokawa, T., Gen, K., Murashita, K., Nomura, K., Kim, S. K., \& Tanaka, H. (2009). Influence of salinity on morphological deformities in cultured larvae of Japanese eel, Anguillajaponica, at completion of yolk resorption. Aquaculture, 293(1-2), 113118. doi: 10.1016/j.aquaculture.2009.04. 005

Prodocimo, V., Souza, C. F., Pessini, C., Fernandes, L. C., \& Freire, C. A. (2008). Metabolic substrates are not mobilized from the osmoregulatory organs (gills and kidney) of the estuarine pufferfishes Sphoeroides greeleyi and S. testudineus upon short-term salinity reduction. Neotropical Ichthyology, 6(4), 613-620. doi: 10.1590/S1679-622 52008000400009
Rahmah, S., Liew, H. J., Napi, N., \& Rahmat, S. A. (2020). Metabolic cost of acute and chronic salinity response of hybrid red tilapia Oreochromis sp. larvae. Aquaculture Reports, 16, e100233. doi: 10.1016/ j.aqrep.2019.100233

Reis, A. B., Sant'Ana, D. D. M. G., Azevedo, J. F. D., Merlini, L. S., \& Araújo, E. J. D. A. (2009). Alterações do epitélio branquial e das lamelas de tilápias (Oreochromis niloticus) causadas por mudanças do ambiente aquático em tanques de cultivo intensivo. Pesquisa Veterinária Brasileira, 29(4), 303-311. doi: 10.1590/S0100-736X 2009000400005

Schwaiger, J., Wanke, R., Adam, S., Pawert, M., Honnen, W., \& Triebskorn, R. (1997). The use of histopathological indicators to evaluate contaminant-related stress in fish. Journal of Aquatic Ecosystem Stress and Recovery, 6(1), 75-86. doi: 10. 1023/A:1008212000208

Smith, M. E., Kane, A. S., \& Popper, A. N. (2004). Noise-induced stress response and hearing loss in goldfish (Carassius auratus). Journal of Experimental Biology, 207(3), 427-435. doi: 10.1242/jeb.00755

Sparks, R. T., Shepherd, B. S., Ron, B., Richman III, N. H., Riley, L. G., Iwama, G. K., \& Grau, E. G. (2003). Effects of environmental salinity and $17 \alpha-$ methyltestosterone on growth and oxygen consumption in the tilapia, Oreochromis mossambicus. Comparative Biochemistry and Physiology Part B: Biochemistry and Molecular Biology, 136(4), 657-665. doi: 10.1016/S1096-49 59(03)00245-8

Ullah, S., Li, Z., Hasan, Z., Khan, S. U., \& Fahad, S. (2018). Malathion induced oxidative 
stress leads to histopathological and biochemical toxicity in the liver of rohu (Labeo rohita, Hamilton) at acute concentration. Ecotoxicology and Environmental Safety, 161, 270-280. doi: 10.1016/j.ecoenv.2018.06.002

Urbina, M. A., \& Glover, C. N. (2015). Effect of salinity on osmoregulation, metabolism and nitrogen excretion in the amphidromous fish, inanga (Galaxias maculatus). Journal of Experimental Marine Biology and Ecology, 473, 7-15. doi: 10.1016/j.jembe.2015.07.014
Varsamos, S., Nebel, C., \& Charmantier, G. (2005). Ontogeny of osmoregulation in postembryonic fish:a review. Comparative Biochemistry and Physiology Part A: Molecular \& Integrative Physiology, 141(4), 401-429. doi: 10.1016/j.cbpb.20 05.01.013

Zuanon, J. A. S., Salaro, A. L., Veras, G. C., Tavares, M. M., \& Chaves, W. (2009). Tolerância aguda e crônica de adultos de beta, Betta splendens, à salinidade da água. Revista Brasileira de Zootecnia, 38(11), 2106-2110. doi: 10.1590/S151635982009001100005 
